\title{
Upward and downward accountability in local government: the decentralisation of agricultural extension services in Tanzania
}

\section{Commonwealth Journal of Local Governance}

Issue 25: December 2021

http://epress.lib.uts.edu.au/ojs/index.php/cjlg

\section{Wilfred U Lameck}

School of Public Administration and Management

Mzumbe University

Tanzania

Email:wlameck@mzumbe.ac.tz

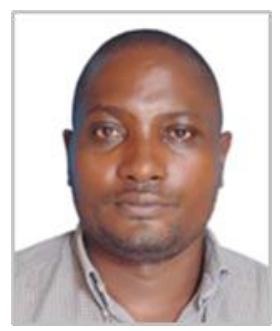

\section{Rudie Hulst}

Department of Political Science and Public Administration

VU University

Amsterdam

The Netherlands

Email: jr.hulst@fsw.vu.nl

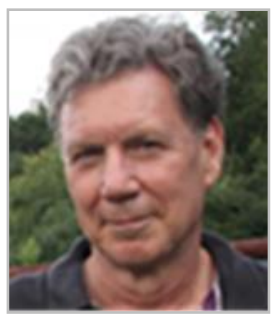

\begin{abstract}
A key assumption behind decentralisation in developing countries is that it enhances the accountability of local government and results in policies that reflect the preferences of the local community. However, previous research shows that local politicians and administrators in many developing countries to a large extent behave as if they were primarily accountable to central government, not local communities. The literature suggests various explanatory factors but does not provide insight into their relative weight and into how different factors interact. This paper combines comparative case-study research with in-depth interviews and focus group discussions with local government politicians and officials involved in the delivery of agricultural extension services in Tanzania. It shows that limited administrative and political decentralisation and centralistic human resources management restrict downward accountability to the community. Downward accountability is also constrained by the social rules that local politicians and administrators observe. For downward accountability to materialise, formal systems of public administration need to introduce incentives to that effect.
\end{abstract}

Keywords: Decentralisation, local government, accountability, Tanzania, agricultural extension services 


\section{Introduction}

This paper reports research concerning accountability in the delivery of agricultural extension services in Morogoro Municipality in eastern Tanzania, and Hai District in the north. The study was carried out between June 2014 and June 2017, and revised in September 2021.

Over recent decades, many developing countries have engaged in the transfer of responsibilities for various aspects of policy-making and public service delivery from central to regional and local government (Crook and Manor 1998, p. 1; Litvack et al. 1998, p. 1). One of the main motives for decentralisation was that the centralised planning and administration of the 1970s and 1980s had failed to produce economic growth and deliver public services at a satisfactory level. A second motive has been that, from the early 1990s, international agencies such as the World Bank and the International Development Bank have pressured countries to transfer responsibilities to lower levels of government. The common assumption was that decentralisation would create proximity between citizens and government, and hence would increase the accountability of local government and result in policies and services that reflected the preferences of local communities (Jutting et al. 2004, pp. 89).

In some developing countries decentralisation is reported to have had a positive impact: it has increased transparency in government and resulted in responsible leadership while reducing the incidence of corruption. For example, in developing countries such as Tanzania, Ghana and Uganda access to and citizens' satisfaction with education and health services increased (Crook and Manor 2000; Bardhan and Mookhergee 2003; Tidemand and Msami 2010, pp. 30-31). Overall, however, positive results fall short of expectations. The quality of local governance and economic performance is still very low, and the capacity of authorities in many countries to address the needs of the local population is very limited. In many cases, the quality of public services has remained unchanged or even declined. Moreover, contrary to the assumption mentioned above, there is a persistent lack of responsiveness: local policies and services do not necessarily reflect the preferences of the local community (Crook and Manor 1998, p. 271 et passim; Wunsch 2013, p. 279; Tidemand and Msami 2010, p. viii).

According to the literature, one explanation for the lack of responsiveness of local government in service delivery is lack of resources: both financial and human capital. A second explanation, however - which has received little attention - is that local officials do not hold themselves accountable to the local community. Instead of taking local preferences into account when deciding on policies and services, they adopt policies or priorities formulated by higher-level governments. They display upward accountability instead of downward accountability (Blair 2000, p. 27 et passim; Schou 2000; Olowu 2001, p. 51; Yilmaz and Venugopal 2008). 
It is widely accepted that decentralisation can never be absolute: macro-economic stability and the redistribution of income require central policies. Also, because of their technical features, some services cannot be provided by local government. Furthermore, questions of merit and national unity can justify some central government regulation of local policies in areas such as education and healthcare. As a consequence, local politicians and officials up to a certain point must defer to national legislation and policies, and account for their actions if so required. The issue discussed in this paper is, however, different: it is that in many cases where local government has been given primary responsibility for decisions on policies and services, local preferences still appear to be given a low priority. Upward accountability still drives out downward accountability.

The literature cited above suggests a number of factors that explain the predominance of upward accountability. How different factors interact in a specific context and which factors carry most weight is a matter for case-by-case investigation. The research reported in this article concerns accountability in the provision of agricultural extension services and implementation of agricultural development plans in Tanzania; services that were decentralised to local government in 1999 as part of the country's 'Decentralization by Devolution' programme (Mattee 1994, p. 180). The research has provided data that enables this paper to address the following questions:

- With respect to agricultural development plans, to what extent do officials in Tanzanian local government display downward accountability since decentralisation?

- How can the relative importance of downward and upward accountability be explained?

Following Blair (2000), Schou (2000) and Dickovick and Riedl (2010), this paper uses a concept of accountability which consists of three elements or types of relationship:

1) the relationship between elected politicians and their constituencies. Accountability can be considered in place if elected politicians are informed about the preferences of those they represent, take these preferences into account at the time of making decisions, and give account of their actions to the electorate;

2) the relationships between elected politicians and appointed administrators. Accountability here would imply that administrators are subject to the instruction and supervision of elected politicians and can be held to account for implementing their decisions; and

3) the relationship between politicians and administrators collectively on the one hand, and the local community on the other. Accountability would be in place if groups or institutions affected by specific policies or services are consulted about their preferences, if these preferences are given due consideration, and if politicians and administrators account for their actions to their respective stakeholders. 
Downward accountability thus refers to the relations between local politicians, local administrators and the local community. Upward accountability concerns the relationship between local politicians and administrators on the one hand, and representatives of higher-level governments on the other. It is in place when local politicians and administrators inform themselves about the preferences and policies of higher-level governments, take these into account first and foremost when taking decisions, and account for their actions primarily to higher-level politicians and officials.

\section{Theory and literature review}

The literature suggests a series of factors that determine the balance between downward and upward accountability. Two categories can be distinguished: first, formal rules that determine how much scope local officials have to display downward accountability and/or that require a certain degree of upward accountability; and second, institutions that set conditions and incentives for local officials to display either downward or upward accountability.

With respect to the first category, many scholars cite the fact that decentralisation undertaken by developing countries has remained incomplete. Although local governments with elected councils have become responsible in law for local policies and services, a substantial body of central rules and supervision remains in place. In many cases, local government plans and budgets are subject to approval by central government. Local governments also depend heavily on national grants, which can come with detailed spending conditions (Blair 2000; Schou 2000; Dickovick and Riedl 2010). Such features of the formal system of public administration limit the autonomy of local officials and force central government policies on local government, thus reducing the possibility of downward, and instead requiring upward accountability.

The more centralising elements the system of public administration contains, the less discretionary space there is for local officials to be responsive to the local community. Nevertheless, when local government has been entrusted with formal responsibility to establish policies or provide services, some degree of local discretion will always be present. In this regard, the literature points to various features of institutions in place that create conditions and incentives for local politicians and administrators to display either downward or upward accountability within the discretionary space available to them. This paper organises its discussion using the three relationships distinguished above, starting with the relationship between local politicians and their constituencies.

According to the literature, an electoral system that allows for multiple parties and facilitates the actual presence of opposition parties in local councils creates incentives for local politicians to take the preferences of their constituency seriously (Blair 2000, p. 27 passim; Schou 2000; Dickovick and Riedl 2010, p. 59). Also, transparency of the local political process, through for example public council meetings, would make sure the electorate is informed about the actual positions and decisions 
their representatives take, so citizens can take these into account when voting in the next elections (Blair 2000). In the same vein, it is argued that the setting of performance targets by the local executive can make service provision more transparent to customers, who can use this information when assessing the value of their representatives (Therkildsen 2001, p. 27). As well, much has been said about the importance of media and civil society organisations. They provide countervailing power necessary to protect local democracy, which citizens as individuals do not have. By monitoring the policies and services of local government, they can make sure politicians are informed about the preferences of the community and pressure them to take those preferences seriously (Blair 2000; Olowu 2001; Ribot 2002; Hoffman 2013).

It must be noted that all these analyses take the framework of classical representative democracy as a starting point. They tend to neglect the role of socio-political culture and the presence of neopatrimonial relationships between politicians and the electorate. In developing countries, and indeed elsewhere, elections are often contested based on personalities, ethnicity and clientelist relationships rather than on the presentation and assessment of clear manifestos. Frequently, the choices presented to citizens are crude, bearing little relationship to policy, budgetary considerations or performance (Prud'homme 1995, p. 208; Johnson 2001).

In addition to the rules of democratic institutions, the way elected politicians interpret accountability is influenced by the institutional features of political parties. Frequently, the national leadership of political parties decides whether a candidate can stand for a local election. Loyalty to the national party manifesto or personal loyalty to the party leadership is then paramount for candidates, both before and after elections (Schou 2000; Ribot 2002; Yilmaz and Venugopal 2008; Dickovick and Riedl 2010). Local politicians who depend on central party organs for the continuation of their office, and possible promotion, will tend to prioritise the directions set out in party manifestos over the preferences of their local constituency: a clear example of upwardly instead of downwardly accountable behaviour.

Turning to the relationship between local politicians and local administrators, several factors seem to play a role. Some relate to the formal relationship between politicians and administrators. A division of responsibilities, in which policy decisions are ultimately reserved for elected politicians, is a precondition for holding administrators accountable for their actions. The use of management tools such as performance targets would support effective oversight of administrators by politicians. However, for administrators to display accountable behaviour towards local politicians the system must also contain incentives. Authority to appoint, promote, sanction and fire administrators must also be the competence of local governments. But in many developing countries it is still central government that decides on the selection, appointment, promotion and salaries of local administrators, even if the policies and services they are assumed to carry out and provide are devolved to elected 
local governments (Blair 2000; Ribot 2002). If local officials depend on central government for their appointment and promotion, it is understandable that the proposals they develop and the decisions they make are guided by one maxim: local policies and plans must conform to what they assume to be national policies and guidelines, even if the latter are not in the interest of the local community. Upward accountability of local administrators may be further entrenched when senior local staff are recruited from the pool of members of the ruling party, as often happens. If that is the case, administrators will often consider loyalty to party manifestos more important than accountability to local politicians (Melyoki et al. 2008, p. 29).

Concerning the third relationship - between local politicians and administrators on one hand, and sectors of the local community on the other - many of the factors mentioned above remain relevant. They determine firstly whether politicians and administrators have discretionary space to allow for local preferences; and secondly the extent to which they adhere to national party manifestos and central government policies respectively, as opposed to the preferences of the local community. It is true that some balancing factors do exist: not just the countervailing power of the media and civil society mentioned above, but also the existence of formal procedures empowering local communities to participate in the development of local plans for specific sectors, and user groups and systems for certain services to keep track of public spending (Dickovick and Riedl 2010). However, research suggests that this type of empowerment is not always sufficient to outweigh upward accountability behaviour on the part of local officials (Mollel 2010).

\section{Research questions and methodology}

Agricultural extension services are loosely defined, but typically consist of: the transfer of knowledge concerning agricultural technology to farmers; assistance to farmers' groups in the development and execution of special projects to enhance production or improve marketing skills; and the collective training of farmers either in field schools or in workshop-like settings. In Tanzania, these services are considered an important means to improve agricultural production and marketing. In 1999, as part of the broader 'Decentralisation by Devolution' reform initiated in the mid-1990s, responsibility for the delivery of agricultural extension services was transferred from the regional branches of central government to local government (Mattee 1994, p. 180). Local governments must formulate a fiveyear strategic development plan which includes a section on agriculture, and includes annual agricultural development plans. They must also decide on the allocation of funds to special projects. Every local government has a department of agriculture responsible for the actual delivery of services and the implementation of projects. Funds for special projects are provided through grants from central government. The main goal of the decentralisation project was to promote demand-driven agricultural services. To that effect, the project included the establishment of a bottom-up planning procedure in which the farmers participate in making plans that reflect their needs (Lameck 2017). 
In view of the above, this paper addresses the following questions, through its case study of Morogoro Municipality and Hai District:

- To what extent were upward and downward accountability revealed by the development process for strategic and annual agricultural development plans?

- To what extent did local politicians display downward or upward accountability at the moment of deciding on the content and adoption of strategic and annual plans?

- To what extent was downward or upward accountability revealed in the implementation of plans by the local administration?

- What factors can explain the patterns of accountability found in the local governments included in the research?

- What could be done to redress any imbalances between downward and upward accountability?

As noted earlier, the research project was a comparative case study of the delivery of agricultural extension services in two municipalities, Morogoro Municipality and Hai District. The two local governments are entrusted with the same formal task, enjoy the same formal decision-making authority and are subject to the same legal rules. However, they differ substantially in terms of geographical setting, population density, political composition of their local councils, and the importance of agriculture in the local economy. The assumption made was that these differences can influence the way extension services are planned, decided on and delivered. In each of the two districts a detailed study was made of the planning and actual delivery of services in three wards (administrative sub-units of a local government district). The research activities included analysis of national and local policy documents, plans, programmes and reports; over 60 semi-structured interviews, involving policy officers at different levels of government, field agricultural extension officers, local politicians, farmers, and representatives of farmers and non-governmental organisations (NGOs) for agriculture and livestock services; 12 focus group discussions with farmers; and a series of observations of meetings between policy officers and farmers, and meetings of the local councils.

\section{How agricultural plans are developed in Tanzania}

The Tanzanian government has adopted the Tanzania Development Vision 2025 (United Republic of Tanzania (URT) 1999), a multi-sectoral document to guide national-level economic and social development and to provide an integrated framework for the preparation of five-year strategic development plans (URT 2021). Under those plans, agriculture is seen as an instrument for the realisation of national development goals. In line with the national plan, the central government requires each local government to develop a general five-year strategic plan that covers all policy sectors under the supervision and coordination of the Regional Secretariat, a regional organ of central government administration. The secretariats were created to provide multi-skilled resources for supporting local development initiatives and to link central government with local government (URT 
1997). To this end, they provided technical support for the strategic plans developed in Morogoro and Hai. Those plans were in turn intended to guide annual development plans, including an agricultural development plan.

\section{The case of Morogoro Municipal Council}

Morogoro Municipality has a population of approximately 320,000 (based on 2012 numbers) and covers an area of $531.6 \mathrm{~km}^{2}$. Administratively, the municipality is divided into 29 wards, which are further divided into a total of 272 'streets'. Politically, the municipality consists of 29 elected ward councillors, ten councillors for special seats, and three members of parliament. The mayor is elected from amongst the ward councillors. There are five permanent committees composed of council members, while the administrative organisation consists of 13 departments and six units. One of the departments covers agriculture, irrigation and co-operatives, and another livestock and fisheries (URT 2016b).

In March 2011 the municipality approved the five-year strategic plan for 2011-16. The plan identified the targets cascaded from the national plan to be reached in the year 2016 and strategies to be used. One of the areas addressed by this strategy was crop production. In the first place, the municipality intended to increase maize production from 2.8 tonnes per hectare to 3.2 in the year 2016 through the use of improved technology, the provision of extension services, subsidised agricultural input and the procurement of agricultural implements. Secondly, the municipality planned to improve paddy production through the use of improved agricultural technologies, traditional irrigation schemes, subsidised agricultural input and extension services, and by training farmers on improved technology (URT 2011b).

In the year 2016, the municipality developed another strategic plan covering the period 2016-21. Unlike the previous plan, the current plan concentrates on reducing post-harvest losses. It aims to: reduce post-harvest loss of green vegetables and tomatoes from $60 \%$ to $40 \%$, through training 1,785 farmers and constructing one tomato processing and packaging unit; reduce post-harvest loss of maize from $40 \%$ to $20 \%$ through training of 7,700 farmers; reduce post-harvest loss of mangoes from $40 \%$ to $20 \%$ through offering training to 1,273 farmers and the provision of 500 litres of insecticide for the eradication of fruit flies; support seven farmers' groups with improved solar driers; and ensure extension service delivery is strengthened from 50\% to $70 \%$ through providing motorcycles, constructing a farmers' exhibition building, and preparing learning materials such as leaflets and posters about improved crop husbandry (URT 2016b).

Although the municipality is required to develop its strategic plan through a detailed SWOT analysis, the plans adopted in both 2011 and 2016 were generalised, with percentages extracted from the national agricultural strategic plan (URT 2016b), and did not reflect the specific problems identified 
by farmers. For example, according to the SWOT analysis for extension service delivery conducted by council officials in the year 2011, local farmers face a problem of insufficient access to advice and agricultural information due to lack of incentives and inadequate working facilities for the extension officers. The farmers also lack modern farm implements and consequently rely on traditional tools such as hand hoes. In addition, they do not have adequate transport to send their crops to market. However, the strategies in the plan to address these issues and increase production appear inadequate. They focus on aspects such as improving agricultural technologies, improving extension services, subsidising agricultural input and buying motorcycles for extension officers, without showing specifically how results will be achieved. Also, the lack of incentives for extension officers, and attention to their specific work needs - such as toolkits for soil analysis, office equipment, rain boots and other items - do not feature explicitly in the plan (URT 2016b). By contrast, the targets to reduce post-harvest loss of crops and vegetables are formulated in percentages. Research participants suggested that these targets were taken from the national plan that is sent to local governments as a guideline (interviews with agricultural and livestock officers). This finding is supported by the fact that the planning process must conform to the national manual for strategic planning and budgeting (URT 2016b) and that technical support was provided by the Regional Secretariat, which issued guidelines for writing the plan.

The plan was also supposed to reflect the opinions of stakeholders. Some stakeholders such as farmers' groups were indeed consulted, but their input was not adopted. For example, they proposed subsidised agricultural inputs and enough extension officers to provide advice and information on modern technology to farmers. But the plan did not mention or reflect these specific interests (interviews with district planning officer and district agricultural and livestock officer). Research participants suggested that it was instead based largely on central government priorities as applied by local officials, based on their long working experience as heads of departments (interviews with municipal planning officer, municipal agricultural and livestock officer, ward councillors).

Interviews with ward councillors revealed that they played only a minor role in preparing the plan. First, they saw themselves as having insufficient skills and knowledge to discuss a technical plan. Second, they thought it was the job of appointed officials to develop the plan because they know about central government guidelines. Third, they believed wrongly that the plan was prepared based on the input of lower-level officials who work directly with farmers. Fourth, they believed that the plan reflects the instructions from central government which provides funds for its implementation, and that they should respect those instructions. This view is also supported by the mayor's statement that the plan must be consistent with the national government plan (URT 2016b).

In order to implement its five-year strategic plan, the municipality must prepare agricultural development plans for each year. While the strategic plan is supposed to be based on national 
guidelines and a local SWOT analysis, the agricultural development plans must be developed according to the formal procedure set out in the central government guidelines (URT 2006b). In Morogoro Municipal Council, the district facilitation team has been trained to apply a bottom-up planning procedure (interview with municipal agricultural extension officer).

According to the guidelines, the planning process begins at the lowest administrative level, the 'street', with around 1,000 inhabitants. Once a year and upon instruction of the municipal director, every street organises a special meeting for citizens to deliberate on their agricultural priorities. The process of planning is supposed to articulate the problems and priorities of the farmers. In practice, extension officers take the lead. They present ideas for projects to farmers for them to discuss. If the farmers present their own proposals for the improvement of production or marketing, the extension officer informs them about the costs and benefits involved in the realisation of such ideas, and whether it will be possible to obtain funds. Both the initiatives of the extension officer and his advice concerning suggestions made by farmers are based on what he thinks conforms to central government priorities (interviews with agricultural extension officers and farmers in the Kilakala, Bigwa and Kichangani wards of Morogoro Municipality).

\section{The case of Hai District}

Hai is one of the districts of the Kilimanjaro region with a population (in 2013) of over 210,000 inhabitants (URT 2013). Its political and administrative structures are very similar to those of Morogoro, but with fewer councillors (14 ward councillors and five for special seats). Again, there are designated departments for agriculture, irrigation and cooperatives, and for livestock and fisheries.

Like Morogoro Municipality, the council adopted a strategic plan which covered the period 2011-16, with a target to increase total food production from 241,800 tonnes in 2011 to 313,160 tonnes in 2016 by training groups of farmers on modern farming techniques to produce maize, rice, bananas and beans, and through the construction of demonstration plots for sorghum production. This was expected to increase maize production by $25 \%$, rice production by $37 \%$, banana production by $1.8 \%$, bean production by $30 \%$, and sorghum production by $100 \%$ (URT 2011a)

In 2016 the council developed a further strategic plan for 2016-21, with targets to increase cash crop production from 0.13 tonnes/ha in 2016 to 0.2 tonnes/ha, and food crops from 3.9 tonnes/ha to 5.04 tonnes/ha through increased availability of agricultural inputs, rehabilitation and construction of new irrigation structures, expanded coffee nurseries, establishing farm field schools and demonstration plots, sensitisation on the use of agro-mechanisation, reduction of post-harvest crop losses and improved storage facilities. However, the projected growth percentages are not locally generated; rather they are more or less copied from central government guidelines sent to local government through the Regional Secretariat (URT 2016a; interview with Director of Planning). 
As in the case of Morogoro, according to the national guidelines stakeholders must be consulted in preparing the plan. But farmers' organisations and cooperatives, which are key stakeholders, were not consulted. Although district officials at the ward level were supposed to collect citizens' opinions in order to inform themselves about their priorities, they did not do so. Even where they did invite citizens to provide their input, the citizens had no knowledge of the plan and did not know what to contribute (interviews with Rundugai and Masama ward councillors). It was only in the last phase of the preparation of the strategic plan that some stakeholders such as community members, traditional leaders and NGOs were consulted (URT 2011b) ; interview with district agricultural extension officer). Also, a draft of the plan was sent to a number of NGOs and community leaders for consultation, but their comments were not included in the document that was submitted to the council for approval.

The subsequent annual agricultural development plan was presented first to the relevant sectoral committee and then the planning and administration committee, which is primarily responsible for advising the full council and coordinates and discusses the input from other sectoral committees. However, in the meetings at which the draft plan was tabled, there was hardly any discussion about its content, the projects included or the allocation of budget to the projects. Instead, the committee meetings were preoccupied by discussion on other items such as revenue collection and cash flow issues. This pattern was repeated in the meetings of the full council (URT 2017).

Once the plans and budgets have been established by the full council, they are submitted to central government for approval. In practice, the Regional Secretariats are the decision-makers. Over recent years, all yearly agricultural development plans for the whole country have been approved without further ado. Given the close involvement of the Secretariat in the development of the plans and the dominant role local officials play, that comes as no surprise.

\section{Comparative assessment}

Firstly, the problems ostensibly facing agriculture in the two districts were very generalised and similar, in spite of big differences in their agro-ecological characteristics (namely climate; lack of modern farm implements and means of transportation; lack of resources for extension services; and a differing adoption rate of new technologies by farmers (URT 2011a, 2011b). Secondly, both plans contained very detailed targets for increased production of different crops and livestock, but did not explain what the targets were based on. They were in fact taken from national documents sent to the local government by the Regional Secretariat. The role of the Regional Secretariat is to provide technical assistance and advice to local government in developing plans, but in both cases the Secretariat's contributions were not taken as advice, but as instructions to be implemented, because in practice local sector policies must conform to planning guidelines provided by central government 
(Research on Poverty Alleviation (REPOA) 2008); interviews with Heads of Department of Agriculture and Livestock at Morogoro and Hai).

With respect to the planning process in Morogoro and Hai, two findings stand out. First, the bottomup procedure was followed: in both local governments street and village meetings took place and the process followed the steps prescribed in the national 'Opportunities and Obstacles to Development' framework (URT 2006a). But second, and in contrast with the goal of the framework, when it came to identifying necessary agricultural projects and the selection of projects to be financed, extension officials played a dominant role. In fact, to a large extent the process consisted of convincing farmers of the relevance of projects the officials interpreted to be in line with central government priorities and to meet conditions attached to central government grants. This was especially the case in urban Morogoro (interviews with ward executive officer and ward agricultural extension officer at Morogoro). In rural Hai District the consultation process was relatively more interactive and farmers sometimes made suggestions (ward agricultural extension officer and village agricultural extension officer Hai). But even in Hai District the officials selected the projects. As in Morogoro, the ward development committees, chaired by the elected ward councillor, approved the drafts submitted to them by the ward facilitation teams without discussion. The district facilitation teams then compiled the ward plans into district plans. In the process, administrators made sure that central government guidelines were taken into account. Examples of this included concentrating efforts on two crops only; selecting only projects that add to the value chain; and financing projects in only a limited number of wards (interviews with Head of Department of Agriculture and Livestock in Morogoro, and district agricultural extension officer and district agricultural and livestock officer in Hai).

After compilation of the ward plans into a draft agricultural development plan, the latter is integrated in the overall annual district development plan and submitted to the Regional Secretariat for 'review and advice'(REPOA 2008). In fact, the Regional Secretariat simply made sure that the district plan abided by guidelines provided by central government, including indicative figures for the available budget (interviews with district planning officer, Hai District Council and municipal planning officer, Morogoro Municipality).

The overall picture concerning the development of strategic and annual plans is that upward accountability of public officials completely dominates: farmers and organisations are either not involved in the planning process - in the case of strategic plans - or if they are, their input is not taken into account. The local officials act as if they have to respond to the central government bureaucracy. This is also the case with the elected ward councillors: instead of articulating the preferences of their constituencies, they simply rubberstamp the ward plans put to them by the administrators, assuming that the plans reflect their party manifesto and central government guidelines and it is pointless to question them (findings of interviews with Morogoro and Hai councillors). 


\section{Accountability in the formulation of agricultural plans}

It is the competence of the local council to approve the strategic and annual agricultural development plans. The procedure is that drafts developed by council staff are first submitted to and discussed in council committees. Apart from the sectoral committees for which the plan is relevant, this always includes the finance and administration committee. Subsequently, plans are tabled at full council for final decision-making. Local government plans are then subject to approval by central government.

The present research found that in both local governments studied neither the council committees nor the full councils discussed the strategic plans in detail. Apart from an occasional question, the council committees hardly paid any attention to the SWOT analyses and the targets included in the strategic plans. The full councils approved the plans as they were submitted. In the process as a whole, no amendments were made to the drafts developed by the council staff (minutes and observations of council meetings of December 2014 in Morogoro and Hai District). As indicated earlier, councillors gave a number of reasons for their passive role. First, some found themselves not competent to assess the technical details of the strategic plans and dared not to question the expertise of the council staff. Second, some argued that they thought the plan was based on the input of low-level officials who directly work with farmers and thus reflected their preferences. Third, and most importantly, they argued that they believed the plans developed by the council staff conformed to central government guidelines, and that they should respect these. A failure to do so could jeopardise their standing for reelection or promotion in their political career (interviews with councillors in Morogoro; and with councillors and council chairperson in Hai).

Strategic plans provide a framework for the planning of activities; however, they do not have direct implications for the allocation of funds. Up to a certain point, one can understand that they do not provoke a lively political debate. However, one would expect greater interest when it concerns annual plans: these contain the projects for which financial resources are made available, and if successful such projects can make a real difference for the farmers involved. As projects are generally confined to one ward or a very limited number of wards, it would make sense for councillors to try and make sure that their constituencies benefit from the funds that become available. One would expect discussions about priorities and the possible efficacy of projects included in the annual plans.

In Morogoro, where all council members were elected from the national ruling party, the annual plans were approved without discussion (minutes and observations of council meetings in Morogoro and Hai District from January to December 2015; interviews with councillors in Morogoro and Hai District). The explanations for the passive role of the councils very much resemble the ones presented above, except for one. With respect to the selection of projects to be financed councillors did not feel that they lacked expertise, but they did believe the plans presented to them reflected the priorities of central government and the ruling party, and that it was not in their interest to question them 
(interviews with councillors in Morogoro): "We are here to implement our party manifesto. It is the party manifesto that determines our career in politics" (interview with councillor in Morogoro).

In Hai District, the authors found that members of the national opposition party, who make up half of the elected councillors, did question the allocation of funds to certain projects. In the end, however, they did not oppose the approval of the annual plan in 2014 because, they argued, the district did not have enough resources of its own to finance extension projects and they did not want to jeopardise the allocation of grants to their district by opposing the plans tabled (interviews with councillors in Hai District).

The present research therefore shows that the process of decision-making by local councils is almost completely dominated by upward accountability. Overall, councillors simply accept the plans submitted to them by the administrative staff. The authors observed no effort whatsoever to articulate specific preferences of the local community as a whole or of specific wards represented by councillors. The fact that discretionary space for local councils is limited plays a role. However, more important is the fact that local councillors are convinced that it is neither their role, nor in their interest, to question plans that they assume reflect the priorities of central government.

\section{Accountability in the implementation of agricultural plans}

The annual agricultural plans approved mainly consist of the extension projects included in the plan. In the case of Morogoro and Hai, these included setting up farmers' groups, acquiring farm implements, agricultural input, educational material, and transport to be used by extension officials in farmers' field schools or training sessions. These projects may face a number of obstacles and risks. One is that the final approval of a local plan that meets the budget ceiling established by central government does not mean that funds will actually flow to local government in time to initiate the projects included. Consequently, local government has to prioritise which of the approved projects can start and which have to be postponed. Second, in many projects financed by central government grants, some kind of matching contribution by local government or the farmers themselves (in kind or in money) is assumed. If this does not materialise, the implementation of projects is at risk. Third, there is always the risk of misuse of funds by the local administration, for example by using central government grants for special allowances to public officials.

The responsibility of local councils for the provision of agricultural extension services implies that they must supervise implementation of the projects included in the agricultural development plan and hold administrators accountable. In contrast with the limited role local councilors play in the development of strategic and annual plans, this study suggests that they are quite active in supervising implementation. First, in the case of the need to prioritise between projects because of lagging cashflow, individual councilors did not hesitate to lobby senior administrative staff for 
implementation of projects in their wards (interviews with ward councillors in Morogoro and Hai District Council). Second, the council committees met quarterly to discuss implementation reports drawn up by the administration and actually probed administrators to find out whether progress had been made and funds had been used properly. Third, council committees inspected the implementation of projects on site. Fourth, council committees did not hesitate to ask for additional information about implementation or to issue detailed instructions to senior administrative staff with respect to revenue collection vital to co-finance projects (minutes of council committees in Morogoro and Hai District Council).

The picture is clear: in the implementation phase councillors defend the interests of the ward they represent, and councils supervise local administrators and hold them accountable for implementing the annual development plan. Councillors can display this downward accountable behaviour safely. The plans and projects have been approved by central government and they do not run the risk of inconveniencing central government or the leadership of the ruling political party. On the contrary, securing the proper implementation of what are considered central government decisions would be assumed to be to their credit.

\section{Analysis and discussion}

This study of accountability in the development and implementation of agricultural plans in Tanzanian local government leaves no room for doubt. In the planning process, including the planning cycle covering the year 2016-21, both elected local politicians and appointed local administrators overwhelmingly display upward accountability, and consultations with affected groups are almost non-existent. Although the decentralisation of extension services was meant to result in local accountability and demand-driven services, and central government issued procedural guidelines to support this, in practice upward accountability dominates almost completely.

The authors suggest several explanations. First, despite the rhetoric of 'Decentralisation by Devolution' reform (Njovu 2013; Munga et al. 2009), administrative decentralisation is very limited. In agriculture, local governments depend on grants that come with specific conditions; national policy documents formulate central government priorities; and local plans and budgets are subject to supervision and approval by central government. Regional Secretariats - representing central government - are closely involved in the development and supervision of local plans and the implementation of projects.

Second, political decentralisation is limited. The national party leadership controls the selection of candidates for local elections; and hence local councillors very much feel that their careers depend on the loyalty they show to the leadership of their political party and party manifesto. Although it was not part of this research, it seems likely that the local organs of the ruling party enforce its grip on 
local politicians and voters, reducing competition at the grassroots level (Croke 2017). All this produces strong incentives for local politicians to display upward accountability.

Third, human resources management is highly centralised. As a corollary of the Local Government Reform Program I, in 1999, full authority was notionally granted to local government over its local staff (URT 1998). However, this authority has been steadily curtailed by the Public Service Act 2004 and a series of Public Service Regulations (Tidemand and Msami 2010, p. 51). A 2007 revision of the Public Service Act established a centralised recruitment system. In practice, central government recruits and allocates not only local executive directors and heads of departments, but the entire staff of health, educational and agricultural services; and only the minister can decide on dismissal (Hulst et al. 2015). In addition, there is a blurred boundary between administration and politics (Croke 2017). The appointment of senior staff is also based on affiliation to the ruling party, and apart from conformity to central government rules, allegiance to the party manifesto has a positive impact on the evaluation of their performance. All this creates strong incentives for council staff to display upward accountability.

These explanations to a large extent coincide with factors already identified in the literature. However, there is a need for further reflection about what is actually happening at local level. It is not surprising that in the end central government guidelines and priorities are reflected in local plans. However, what is surprising is that local officials, especially local councillors, do not in any way discuss the plans put to them or question the proposals to allocate financial resources to certain projects. Central government guidelines and priorities are not so precise that they leave no options at all. If central government issues a directive to select agricultural extension projects in a limited number of wards, to concentrate efforts on two crops, or to select projects which add to the value chain, there is still ample room for local governments to determine the detail. Councillors could decide to select projects which they think would be more urgent than those suggested by the council staff. As well, farmers, ward extension officers and ward councillors could have a serious debate about which projects should be included in a ward plan and would contribute more to the value chain. All this could take place within the limits of the discretionary space set by central government and would present the opportunity to better attune plans and projects to local circumstances and preferences. However, judging by the situation in Morogoro and Hai District, no serious debate or discussion of this kind takes place. This cannot be explained by the limited administrative decentralisation, or by the strong upward accountability incentives created by the political institutions or the centralised system of management of the local staff: these factors do not directly result in one specific strategic or annual plan.

The authors therefore suggest that the upward accountability of local politicians and administrators is not primarily the result of calculated behaviour, where actors in every situation weigh their options 
and decide which will serve their personal interest most; but rather that local government suffers from a culture of upward accountability. Using the concept of culture as a set of social (that is, informal but shared) rules that guide actors' behaviour (Huizenga 1995), a distinction can be drawn between rules that guide the interpretation of social reality and rules that forbid or prescribe a certain behaviour in certain circumstances (Huizenga 1995). One interpretation rule found amongst local councillors is that proposals or plans submitted to them by the council staff reflect the priorities of central government. In addition, local councillors subscribe to the decision rule that you must not question or go against central government priorities. The combination of these two rules relieves councillors of the duty to scrutinise proposals, suggest alternatives, or argue that any such alternatives would also meet the guidelines and priorities set by central government - which is what a councillor should do to find the right balance between downward and upward accountability.

\section{Conclusion and recommendations}

What could be done to achieve a better balance in the Tanzanian context? The present research suggests that it would not do to simply increase the degree of local autonomy: that is, reduce central guidelines and make local government less dependent on conditional grants. As long as the career of local councillors and staff depends on their loyalty to the leadership of the ruling party and central government, incentives for upward accountability will remain strong and there is no reason to believe that the two social rules identified above will be substituted by others. The key seems to lie in changing the incentive structure. One suggestion would be to enhance the involvement of the local community in the nomination of candidates for local elections. Because the Tanzanian electoral system requires that councillors are elected to represent a ward, this involvement should be organised at the ward level, for example by giving villages and streets the opportunity to discuss the nomination of candidates for election.

Second, currently local elections are held concurrently with those for national parliament and the president. If local elections were held separately from national elections, this would increase the scope for local themes and issues to be debated; and if local councillors were chosen because of their views on the development of the local community, it would create incentives for downward accountability. Third, although Tanzania has a multi-party system, the requirements to establish a new political party are quite strict. The legislation in place does not provide an opportunity to start a local political party, nor does it allow a citizen to stand for political office as an independent candidate. Allowing for more political competition at the local level could give rise to social rules that required politicians to be more accountable to their community (Hiskey 2006; Lankina 2008; Collord 2021).

In addition, it would be necessary to change the incentive structure for local administrative staff. Giving local governments the full authority to select, appoint and manage their staff would foster the development of social rules that prescribe loyalty to the elected council and thereby support 
downward accountability. However, this involves a number of risks. Nepotism at the local level can easily result in the appointment of unqualified staff and produce local administrative systems prone to clientelism and corruption. Moreover, from a national perspective, it can lead to the unequal distribution of scarce qualified staff, leaving districts that are unattractive to highly trained professionals without the necessary human resources (Njovu 2013; Munga et al. 2009; Lodenstein and Dao, 2011; Kinemo at al. 2015). Centralised recruitment seeks to avoid these drawbacks, and to provide for an equal distribution of staff with necessary qualifications. Therefore, arrangements for hiring and firing senior local staff should give both local and central government a significant role. One way to do so would be to give the council (or a council committee) the right to nominate or choose a candidate from a shortlist provided by central government. This would enable central government to ensure an equitable distribution of qualified senior local staff, but also make local officials aware that in the end, it was the local council that endorsed their appointment. In addition, one could give local councils the authority to impose disciplinary measures in the case of obvious misconduct, or introduce a rule that a senior official cannot be appointed to another public office without an honourable discharge by the local government he or she served previously. All this could create a context where social rules can emerge to counterbalance upward accountability.

To introduce the measures that are suggested here would require wise and courageous leadership. For democracy to survive in the long run, one must create opportunities for dissenting opinions and for the occasional change of power from one political force to another (Przeworski 2016 )

\section{Declaration of conflicting interest}

The author declared no potential conflicts of interest with respect to the research, authorship, and/or publication of this article.

\section{Funding}

The authors received no financial support for the research, authorship, and/or publication of this article.

\section{References}

Bardhan, P. and Mookhergee, D. (2003) Decentralization and accountability in infrastructure in developing countries. Mimeo: Boston University.

Blair, H. (2000) Participation and accountability at the periphery: democratic local governance in six countries. World Development, 28 (1), 21-39. https://doi.org/10.1016/S0305-750X(99)00109-6

Collord, M. (2021) Tanzania's 2020 election: return of the one-party state. Paris, France: Études de l'Ifri, Ifri.

Croke, K. (2017) Tools of single party hegemony in Tanzania: evidence from surveys and survey experiments. Democratization, 24 (2), 189-208. https://doi.org/10.1080/13510347.2016.1146696

Crook, R. and Manor, R. (2000) Democratic decentralization. OED Working Paper Series 11. Washington DC: World Bank.

Crook, R.C. and Manor, J. (1998) Democracy and decentralization in South Asia and West Africa: 
participation, accountability and performance. Cambridge: Cambridge University Press.

Dickovick, J.T. and Riedl, R. (2010) Comparative assessment of decentralization in Africa: final report and summary of findings. Mozambique: USAID.

Hiskey, J.T. (2006) Principals, agents, and decentralized democratic development: a conceptual framework for democratic local governance. Washington DC: USAID (United States Agency for International Development) and the Urban Institute.

Hoffman, B.D. (2013) The limits of top-down reform: budget transparency in Tanzania. In: Khagram, S., de Renzio, P. and Fung, A. Open budgets: the political economy of transparency, participation and accountability, (pp. 128-144). Washington DC: Brookings Institution Press.

Huizenga, F.D. (1995) Regime analysis: a rule-based method for studying institutions. Administration \& Society, 27, 361. https://doi.org/10.1177/009539979502700303

Hulst, R., Mafuru, W. and Mpenzi, D. (2015) Fifteen years after decentralization by devolution: politicaladministrative relations in Tanzanian local government: political-administrative relations in Tanzanian local government. Public Administration and Development, 35 (5), 360-371. https://doi.org/10.1002/pad.1743

Johnson, C. (2001) Local democracy, democratic decentralization and rural development: theories, challenges and options for policy. Development Policy Review, 19, 521-532. https://doi.org/10.1111/14677679.00149

Jütting, J., Kauffmann, C., Donnell, M.C., Osterrieder, I., Pinaud, H. and Wegner, L. (2004) Decentralization and poverty in developing countries: exploring the impact. OECD Working Paper 236. Paris, France: OECD Development Centre. https://doi.org/10.2139/ssrn.583762

Kinemo, S., Ndikumana, E., Kiyabo, H., Shilingi, V., Kwayu, M. and Andrea, P. (2015) Decentralization of human resource management in Tanzanian governmental organization. In: de Ridder, J. Emans, B., Hulst, R. and Tollenaar, A. (eds.) Public administration in Tanzania, current issues and challenges. African Public Administration and Management Series, Vol. 3. Leiden: African Studies Centre.

Lameck, W.U. (2017) Decentralization and the quality of public service delivery in Tanzania. PhD thesis, Amsterdam: VU University.

Lankina, T. (2008) Cross- cutting literature review on the drivers of local council accountability and performance. Social Development Working Paper No. 112. Washington, DC: World Bank.

Litvack, J., Ahmad, J. and Bird, R. (1998) Rethinking decentralization in developing countries. Washington DC: World Bank Sector Studies Series. https://doi.org/10.1596/0-8213-4350-5

Lodenstein, E. and Dao, D. (2011) Devolution and human resources in primary health care in rural Mali. Human Resources for Health, 9, 1-6. https://doi.org/10.1186/1478-4491-9-15

Mattee, A.Z. (1994) Reforming Tanzanian extension system: the challenge ahead. African Studies Monographs, $15,177-188$.

Melyoki, O., Mafole, G. and Urio, I. (2008) Africa local council oversight and social accountability project: case council report covering Bagamoyo DC, Morogoro Municipal Council, Karatu district council and same district council. Dar es salaam: ALCOSA.

Mollel, H. (2010) Participation for local development. The reality of decentralization in Tanzania. Leiden: African Studies Centre.

Munga, M.A., Songstand, G.N., Blystad, A. and Maestad, O. (2009) The decentralization-centralization dilemma: recruitment and distribution of health workers in remote districts of Tanzania. BMC International Health and Human Rights, 9, 1-11. https://doi.org/10.1186/1472-698X-9-9

Njovu, F. (2013) Experience of decentralized and centralized recruitment systems in local government authorities of Tanzania: a case study of two local government authorities in Morogoro Region. Netherlands: Institute of Social Studies.

Olowu, D. (2001) Local institutional structures and processes: recent experience in Africa. Public Administration and Development, 23, 41-52. https://doi.org/10.1002/pad.258

Prud'homme, R. (1995) The dangers of decentralization. The World Bank Research Observer, 10, 201-220. https://doi.org/10.1093/wbro/10.2.201 
Przeworski, A. ( 2016 ) Democracy: a never-ending quest. New York: Department of Politics, New York University.

Research on Poverty Alleviation (REPOA) (2008) The oversight process of local councils in Tanzania. Final report. Dar es Salaam: REPOA.

Ribot, J. (2002) African decentralization. local actors, powers and accountability. Geneva: UNRISD/IDRC.

Schou, A. (2000) Democratic local government and responsiveness: lessons from Zimbabwe and Tanzania. International Journal of Comparative Sociology, 41 (1), 121-143. https://doi.org/10.1177/002071520004100107

Therkildsen, O. (2001) Efficiency, accountability and implementation. public sector reform in East and Southern Africa. Geneva: UNRISD.

Tidemand, P. and Msami, J. (2010) The impact of local government reforms in Tanzania. Special paper 10/1. Dar es Salaam: REPOA.

United Republic of Tanzania (URT) (1997) Regional Administration Act. Dar es Salaam: Government Printer.

United Republic of Tanzania (URT) (1998) Policy paper on local government reform, local government reform programme. Dar es Salaam: Ministry of Regional Administration and Local Government.

United Republic of Tanzania (URT) (1999) The Tanzania development vision 2025. Dar es Salaam: Planning Commission.

United Republic of Tanzania (URT) (2006a) Agricultural sector development programme, guidelines for district agricultural planning and implementation. Dar es Salaam, Tanzania: Ministry of Agriculture, Livestock and Fisheries,

United Republic of Tanzania (URT) (2006b) Agricultural sector development programme, support through basket fund. Government programme document. Dar es Salaam, Tanzania: Ministry of Agriculture, Livestock and Fisheries.

United Republic of Tanzania (URT) (2011a) Hai District Council Strategic Plan 2011-2016. Tanzania: Prime Minister's Office, Regional Administration and Local Government Authorities, Kilimanjaro Region.

United Republic of Tanzania (URT) (2011b) Morogoro Municipal Council Strategic Plan. Tanzania: Prime Minister's Office, Regional Administration and Local Government Authorities, Morogoro Region.

United Republic of Tanzania (URT) (2013) Tanzania in figures. Dar es Salaam, Tanzania: National Bureau of Statistics, Ministry of Finance.

United Republic of Tanzania (URT) (2016b) Morogoro Municipal Council Strategic Plan 2016/20172020/2021. Dar es Salaam, Tanzania: The President's Office, Regional Administration and Local Government Authority, Morogoro Region.

United Republic of Tanzania (URT) (2016a) Hai District Council Strategic Plan 2016/2017-2020/2021. Tanzania: The President's Office, Regional Administration and Local Government Authority, Kilimnanjaro Region.

United Republic of Tanzania (URT) (2017) Hai District Council minutes of the meeting of Finance, Administration and Planning Committee 2015/2016. Kilimanjaro: Hai District Council.

United Republic of Tanzania (URT) (2021) National five year development plan 2021/22-2025/26 "Realising Competitiveness and Industrialization for Human Development”. Dar es Salaam: Ministry of Planning.

Wunsch, J.S. (2013) Analyzing self-organized local governance initiatives: are there insights for decentralization reforms? Public Administration and Development, 33, 221-235. https://doi.org/10.1002/pad.1652

Yilmaz, S. and Venugopal, V. (2008) Local government discretion and accountability in Ethiopia. Atlanta: Georgia State University. 